\title{
Analysing the relationship between unemployment benefits and unemployment duration
}

\author{
LAURA JUŽNIK ROTAR ${ }^{1 *}$ (1) and SABINA KRSNIK ${ }^{2}$
}

\author{
${ }^{1}$ Faculty of Economics and Informatics, University of Novo Mesto, Slovenia \\ ${ }^{2}$ Faculty of Health Sciences, University of Novo Mesto, Slovenia
}

Received: 25 November 2019 • Revised manuscript received: 24 March 2020 • Accepted: 30 March 2020

Published online: June 18, 2020

(C) 2020 The Author(s)

\section{ABSTRACT}

The aim of this paper is to analyse the relationship between unemployment benefits and durations of unemployment with respect to different approaches in social policy. The hypothesis of the research is that unemployment benefits negatively affect the duration of unemployment. An analysis of the relationship concerning unemployment benefits and duration of unemployment within the European Union Member States (EU-28) between 2006-2018 using panel data regression approach was conducted. The sample was split into sub-samples in order to get more homogeneous groups of EU-28 countries. Estimation results suggest that the more generous a social policy, the more prevalent the negative relationship between unemployment duration and unemployment benefits. Our results also revealed that the better the economic situation, the less pressure is put on unemployment benefits and on the duration of unemployment.

\section{KEYWORDS}

labour market, unemployment duration, unemployment benefits, social policy, EU

\section{JEL-CODES}

C51, J64, J68

\footnotetext{
*Corresponding author. E-mail: laura.juznik-rotar@uni-nm.si
} 


\section{INTRODUCTION}

Social policies are a set of complementary public policies aimed at ensuring social protection and welfare as a moral and political requirement. They also function as an economic necessity, providing more social cohesion and opportunities, and therefore more social stability and chances for economic growth. Countries try to minimize mistakes that occur in the labour market with a variety of regulations, the most paramount of which are labour market policies. These set goals, develop measures and provide resources and activities for the regulation of the labour market. The key question is how a country should interfere with labour market activity to achieve a balance between economic efficiency and social security.

Unemployment insurance systems also have an important role in the function of the labour market and its performance. Public income support for the unemployed, whether in the form of unemployment insurance or assistance programmes, serves two main policy objectives. First, these programmes protect individual workers against the risk of income loss during unemployment and enable consumption between unemployment and employment spells. They can also mitigate the risk of wage losses upon re-employment (compared to the situation before job loss) by allowing workers to spend more time finding a job suitable for their skills and attributes. Second, unemployment insurance programmes help ensure a fair distribution of income and prevent poverty (Hijzen - Salvatori 2020).

In context of unemployment insurance systems, a country's national government is responsible for financing unemployment benefits, whereas the implementation of the unemployment and related policies is usually left to lower levels of a government. This can lead to poorly designed and implemented activation policies, which prove to be less effective in lowering unemployment, thereby pushing up the costs of unemployment benefits at the national level (Beblavý - Lenaerts 2017). Unemployment benefits represent anticyclical budgetary costs that act when unemployment grows and the economy is facing decreasing activity. Unemployment benefits represent an instrument to support the income of unemployed individuals. Simultaneously, resulting from their multiplication effects, they also support consumption and automatically contribute to the increase of aggregate demand (Trasca et al. 2019).

The existing literature suggests that unemployment benefits change the behaviour of unemployed people. The unemployed determine their reservation wage, which represents the equilibrium outcome of the wages offered by employers and of a job seeker's preference (Williamson 2006). The reservation wage enables the comparison of the advantages and disadvantages between job searching and remaining unemployed. More generous welfare systems do not only increase the reservation wage of the recipients, but also encourage a less intensive search for new employment in comparison with unemployed persons who are not entitled to unemployment benefits. This results in a negative influence on employment and the prolongment of unemployment durations, which was confirmed in several studies (Delgado et al. 2019; Hornstein - Lubik 2015; Marinescu - Skandalis 2018; Rothstein 2011; Schmieder et al. 2015; Tatsiramos - Ours 2012).

Such moral hazards link to the ongoing debate regarding the appropriate amount of cash transfers. This balance should consider whether the unemployed person would be safe enough, whilst still encouraged to actively search for a job. An unemployed person who receives unemployment benefits has less motivation to reintegrate into the labour market, in comparison to a situation where they did not receive benefits. In addition to the monetary amount of cash 
transfers, the intervals between receiving benefits is also important. A longer hiatus in receiving unemployment benefits can lead to loss of motivation for reintegration into the labour market (see, for example, Halaskova 2018). The effects of unemployment benefits on the labour market are numerous and often contradictory. At a macro level, some studies (see, for example, Fradkin - Scott 2017; Italo 2019; Marinescu 2017; Rebollo-Sanz - Rodríguez-Planas 2018) have established that longer unemployment benefit claims have a negative impact on search intensity. At the micro level, Lichter (2017) demonstrated that longer unemployment benefit claims decrease search intensity measured two months after the start of the unemployment spell. Barbanchon et al. (2017) however argued that longer durations do not affect the reservation wage that job seekers declare when they register as unemployed.

The effects of unemployment benefits on the labour market depend particularly upon the characteristics of the social policy system. This includes the conditions for acquiring and maintaining benefits as well as their implementation in practice, labour market conditions, and characteristics of labour supply and demand. The aim of this paper is to analyse the relationship between unemployment benefits and durations of unemployment with respect to different approaches in social policy. The hypothesis of the research is that unemployment benefits have a negative relationship with the duration of unemployment. We aim to analyse this relationship on the level of the European Union Member States (EU-28) for the period between 2006 and 2018 using a panel data regression approach. The sample was split into sub-samples in order to get more homogeneous groups of EU-28 countries.

The structure of the paper is as follows: following the literature review, we present the data and methods used in empirical research. The following two sections provide the results and their discussion, as well as the presentation of their implications. The final section concludes.

\section{LITERATURE REVIEW}

The design of unemployment insurance systems, including their role for redistribution, depends on the broader features of tax and benefits systems, notably that of social assistance (Hijzen Salvatori 2020). There is great diversity among the national unemployment insurance systems across the EU. Each EU country has its own laws determining what benefits a person is entitled to, for how long they are entitled to them, how long they must work before qualifying for unemployment benefits, the rules for calculating benefits and the duration of the benefits. Social systems in the EU are highly developed, however, most academics agree that rather than a single European model of social policy, there are five social policy models in Europe, defined as Nordic, Anglo-Saxon, Continental, Southern European and Central Eastern European (CEE).

The countries of Northern Europe are represented by Denmark, Estonia, Finland, Iceland, Latvia, Lithuania, Norway and Sweden. They share the same political aim of promoting social cohesion (Ferrera 2013). Their social model is known for a unique set of shared attributes: respect for democratic traditions, social inclusion, equality, solidarity, transparency, regard for the natural environment and mutual trust (Dospial-Borysiak 2017). The concept of equality is widely perceived - it is not only limited to income equality, but focuses on equal opportunities and equal treatment. Social assistance does not stand as the last income source for those who can no longer take care of themselves, but is provided as a preventative measure (Lauzadyte-Tutliene et al. 2018). These countries consistently top international rankings that assess the rule of law, 
protection of human rights, wealth, innovation, gender equality and the quality of public services (Dospial-Borysiak 2017). Therefore, they have the highest index of quality of life, welfare and equality (Nordic Welfare Centre 2020). A further distinguishing characteristic is the high level of confidence citizens have in their public system. The system relies on the active participation of the state in all significant areas. As a result, the relationship between Northern European populations and their relevant state can be described as close, positive and cooperative (DospialBorysiak 2017). However, the high standards of living and generous benefits result in high taxes, implicating the importance of ensuring low unemployment rates (Lauzadyte-Tutliene et al. 2018).

Anglo-Saxon countries (United Kingdom and Ireland) are identified by the provision of social benefits to all who are in need by the welfare state, the funds of which are accumulated predominantly through taxation (Popova - Kozhevnikova 2013). Social transfers are smaller than in other models and the state emphasises the responsibility of individuals for themselves (Mathieu - Sterdyniak 2008). In these countries, employment rates are higher than the EU average and their welfare appears sustainable from an economic point of view. Contrary to this, trade unions are not as effective; there is higher income dispersion and more low-wage employment. The attitude to markets is quite liberal. Labour markets are not regulated; labour relations are decentralised and bargaining takes place primarily at the firm level. The main characteristic is a low level of expenditure on social protection and its social assistance of last resort. Unemployment benefits are low and only marginally higher than the subsistence minimum (Mathieu - Sterdyniak 2008). Previous employment defines the access to benefits, meaning that those who have not yet been employed would not be entitled to such welfare support.

Continental countries include Austria, France, Germany, Belgium and Luxembourg. Social support in continental countries on average is given to those who have already been present on the labour market. Subsidy calculations depend on the social accumulation of the relevant person (Ferrera 2013). Social protection is organised on an occupational basis and aims at guaranteeing wage incomes. Accordingly, transfers are financed through employer and employee contributions (Mathieu - Sterdyniak 2008). This system is seen as a middle ground between the Nordic and Anglo-Saxon structures. The system is based on the principle of security and identified by numerous laws regarding employment protection and industry regulations. The labour market tends to be rigid and slow to react to globalisation. Governments provide generous unemployment benefits and a well-funded welfare state is conducive for poverty reduction. Although membership fees are low, trade unions do have power of decision in collective agreements (Ferrera 2013).

The Southern Europe region includes Albania, Bosnia and Herzegovina, Cyprus, Greece, Italy, Spain and Malta. Social policies in Southern European countries are based principally on the family having the main role in supporting its socially unprotected members (Popova Kozhevnikova 2013). This is similar to systems in continental countries, yet the labour market is not very flexible due to employment protectionism. However, the system is not so efficient at decreasing poverty. Welfare is mainly directed towards generous state pensions and early retirement as a means to optimize work conditions. Consequentially, the level of social assistance is considerably lower than in other countries (Kluzen et al. 2010). Southern European countries have more segmentation of status and right; therefore access to social provisions is very much conditioned. Trade unions in these countries generally have large memberships, 
which could lead to lower income dispersion (EASPD 2014). Their social model is labelled as conservative and characterized by low levels of participation by women in the labour market, dependency on social contributions instead of taxes, and higher levels of unemployment.

The countries of Central Eastern Europe (CEE) include Bulgaria, the Czech Republic, Estonia, Hungary, Lithuania, Latvia, Poland, Romania, Slovenia and Slovakia. They are united in a social system based on a common history of political governance before 1990. Since there are major differences between the countries, there are also diverse instruments applied. In the mid90s, many CEE governments undertook social-policy reforms. Approaches to reform differed country-to-country. Poland for example has increased its welfare effort; Bulgaria chose to decrease expenditures (EASPD 2014). Social transfers in CEE countries are quite small. There is greater gender discrimination as women are less included, their employment levels are lower and there are gender pay gaps (Lauzadyte-Tutliene et al. 2018). On the other hand, they present more moderate levels of economic growth and inflation. The Baltic States are considered to belong to the CEE group. Their welfare systems are characterised by high inequalities, low social expenditure and low social inclusiveness (Bohle - Greskovits 2007).

Considering these different approaches to social policy, there are many studies that focus on the relationship between unemployment benefits and unemployment duration. Tatsiramos (2006) focused on the impact of unemployment benefits on unemployment durations. The results suggest that the period of unemployment for the recipients of unemployment benefits is considerably longer than for the unemployed who are not eligible for compensation. In addition, Tatsiramos came to the conclusion that although unemployment benefits have a negative impact on the duration of unemployment, there is a positive, indirect effect on the duration and stability of the subsequent employment. Recipients of unemployment benefits stay employed from 2 to 4 months longer than non-recipients on average, which represents for as much as a 10-20 per cent increase in relation to the average duration of employment. A number of studies (Fujita 2010; Hornstein - Lubik 2015; Schmeider - Wachter 2016) give empirical evidence that unemployment benefits reduce the pressure on unemployed persons to accept the less appropriate or worse paid job, which lead to longer durations of unemployment. Schmeider et al. (2015), using the regression discontinuity method based on rich administrative data in Germany, found that a longer period of receiving unemployment benefits allows individuals to find better employment pertinent to their abilities, competencies and experiences. Groot and Klaauw (2014) also came to similar conclusions. They studied the effect of a reduction in the unemployment benefits system on the labour market. Through empirical analysis, the authors used data provided by Statistics Netherlands and specified a regression model to estimate the effect. The results indicated that reducing the time of entitlement to the rights leads to a higher rate of employment. As a consequence, unemployed individuals accept worse or lower paid jobs. This leads to more frequent changes in employment. Kyyrä and Pesola (2017a) also studied the effects of the duration of entitlement to unemployment benefits on employment stability. The study showed that the reduction of entitlement leads to faster employment. However, it also leads to a shorter average duration of employment, which means faster return among the unemployed.

Several recent studies evaluated the effect of increases in the duration of unemployment benefits during the Great Recession using survey data and time variation in benefits (e.g. FarberValletta 2015; Kroft - Notowidigdo 2016; Rothstein 2011; Valletta 2014). Although the magnitude of findings is not immediately comparable between studies due to differences in 
methodology, overall findings suggest unemployment benefits had a significantly negative but moderate effect on unemployment duration.

By becoming unemployed, reduction of income represents an important cause of psychological distress to an individual. A logical step to reduce this stress should be to search for new employment. However, the potentially higher compensation from unemployment benefits in comparison with the previous income leads to a lower motivation for finding new employment (van Beek 2011). To maintain motivation effectively, it would be crucial to support unemployed people in a way that increases chances of the individual's likelihood of returning to the labour market (see, for example, Scrutinio 2019; Stefanovska-Petkovska - Bojadziev 2017). It is important that consultants on the Employment Services devote enough attention to discussions with unemployed persons. The unemployed, particularly long-term, as well as first time unemployed people need motivation after a long period of work, communication and assistance in finding new employment. Van Beek (2011) further notes that financial compensation alone is not sufficient because it has no effect on the psychological implications caused by unemployment. These factors are necessary for the stimulation of the unemployed to actively search for new employment. Južnik Rotar (2013) described similar findings. In order to distinguish the effects of labour market policy expenditures on the unemployment rate, she separately analysed the effects of expenditures for active and passive labour market policies on unemployment rates using panel regression analysis. The findings suggest that mere passive employment policy does not encourage individuals enough to find a job, which should make countries strive to shift from passive to more active interventions. In the study, a strong link between high expenditures on unemployment and a high level of unemployment is demonstrated, which suggests that passive interventions are not as effective. Laporšek and Dolenc (2012) reported similar findings. Using panel regression, including different macroeconomic variables (such as GDP, tax wedge, trade union density and long term unemployment rates etc.) they concluded that ridged employment protection and high expenditures for passive labour market policies negate productivity growth.

Long-term unemployment represents a serious problem not only for the economy, but also for individuals. Aaronson et al. (2010), who studied this problem, found that the likelihood to find employment is reduced with prolonged durations of unemployment. This issue was also exposed by Hassett (2014), who claimed that those who are unemployed for shorter periods of time have more chance to find new employment, as opposed to a person who is required to explain a long period of unemployment. Tvrdon (2015) performed a panel regression analysis to estimate the impact of various institutional aspects on the unemployment rate and long-term unemployment. Results indicated that the total tax wedge and active labour market policies have the most significant influence. While a higher tax burden significantly increased unemployment rates, active labour market policies worked in contrast and may offset the negative effect of high labour taxation of (for example in the Northern countries). Research by Dolenc et al. (2012) was based on microdata and employed regression analysis and different tools of survival analysis. The results indicated that the likelihood of persisting in unemployment increases with age, with a greater number of years of service and with the duration of unemployment benefit entitlement. The last effect was supported in several studies (e.g. Card et al. 2015; Schmieder 2016) and the results show a statistically significant impact on the behaviour of unemployed people.

In addition to the duration of entitlement to unemployment benefits, its amount has also an important impact on the length of search for employment. More generous unemployment benefit systems increase pressure for higher wages in new employment. Companies become less 
likely to create vacancies, which means that unemployed people have more difficulty in gaining employment. The more generous unemployment benefits system can cause less intense search for employment because higher compensation means less to lose if a person stays unemployed (Fujita 2010; Kyyrä - Pesola 2017b). The effect of unemployment benefits on the duration of unemployment is consequently higher in countries with more generous systems (Scrutinio 2019; Tatsiramos 2006).

A large body of evidence shows that the impact of unemployment benefits is most evident on the exit points from unemployment. The literature focussing on these exit points (FarberValletta 2015; Fujita 2010; Nekoei - Weber 2015; Rothstein 2011; Rothstein - Valletta 2017) demonstrates statistically significant effects of unemployment benefits on the probability of exit from unemployment. An exit point is significantly more likely when unemployment benefits expire: job search intensity increases when benefit expiration approaches. Marinescu and Skandalis (2018) claimed that workers progressively increase their search effort and decrease their reservation wage over time to increase their chance to find a job as their remaining unemployment benefits decrease. The study highlighted a significant increase in search effort around benefit exhaustion within an individual spell, corresponding to an increase in search intensity during the months prior to benefit exhaustion, followed by a symmetrical decrease. This decrease is surprising, as these individuals should have an incentive to exit unemployment when they receive no unemployment benefits. However, this can be linked to other social transfers, which are more generous in some countries.

Dolenc et al. (2012) also concluded that unemployment benefit recipients wait until benefit expiration. The increase in exit from unemployment in the time of benefit exhaustion indicates that rightful recipients exploit unemployment benefits till the end, before searching for new employment. A similar effect is seen through the reduction of replacement rates from a higher to lower baseline, although the effect is smaller. Furthermore, they claim that receiving unemployment benefits reduces the probability of exit from unemployment by half (approximately). Results indicated that higher replacement rates and higher unemployment benefits are connected with lower transitions from unemployment. One of the key policies considered best suited to deal with the main challenges of the labour market in the EU until 2030 is the improvement of social policies and protection (Lengyel et al. 2017)

\section{DATA AND METHODOLOGY}

\subsection{Data}

Our data vector consists of unemployment by duration $\left(U D a_{\mathrm{it}}, U D b_{\mathrm{it}}, U D c_{\mathrm{it}}, U D d_{\mathrm{it}}, U D e_{\mathrm{it}}\right)$, unemployment benefits $\left(U B_{\mathrm{it}}\right)$, unemployment rate $\left(U R_{\mathrm{it}}\right)$, unemployment rate by education $\left(U R E 1_{\mathrm{it}}, U R E 2_{\mathrm{it}}, U R E 3_{\mathrm{it}}\right)$, vacancy rate $\left(V R_{\mathrm{it}}\right)$, gross domestic product $\left(G D P_{\mathrm{it}}\right)$, active population by education attainment level - tertiary education $\left(A P E_{\mathrm{it}}\right)$, tax wedge $\left(T W_{\mathrm{it}}\right)$. The data sources are presented in Table 1.

Unemployment rates $\left(U R_{\mathrm{it}}\right)$ are the number of unemployed people as a percentage of the labour force, where the latter consists of the unemployed plus those in paid employment or selfemployment. Unemployed individuals are those who report that they are without work, are available to work and have actively sought work in the last four weeks. The rate relates to people aged 15 to 64 , as a percentage of active population. 
Table 1. Data sources

\begin{tabular}{|l|l|}
\hline Variable name & \multicolumn{1}{c|}{ Data source } \\
\hline$U D$ & OECD database [dur_d] \\
\hline$U B$ & DG Employment, Social Affairs and Inclusion [Imp_expsumms] \\
\hline$U R$ & Eurostat database [une_rt_a] \\
\hline$U R E$ & Eurostat database [une_educ_a] \\
\hline$V R$ & Eurostat database [ei_Imjv_q_r2] \\
\hline GDP & Eurostat database [nama_10_gdp] \\
\hline$A P E$ & Eurostat database [Ifsq_agaed] \\
\hline$T W$ & OECD database [taxing_wages] \\
\hline
\end{tabular}

Source: authors.

Unemployment rates by education $\left(U R E 1_{\mathrm{it}}, U R E 2_{\mathrm{it}}, U R E 3_{\mathrm{it}}\right)$ are measured for persons aged 15-64 years with less than primary or lower-secondary education (ISCED levels 0-2) as a percentage of the active population (URE1 $\left.1_{\text {it }}\right) . U R E 2_{\text {it }}$ refers to persons aged 15 to 64 with upper secondary and post-secondary non-tertiary education (ISCED levels 3 and 4) as a percentage of active population, while $U R E 3_{\text {it }}$ refers to person aged 15 to 64 with tertiary education (ISCED levels 5-8) as a percentage of active population.

Unemployment by duration $\left(U D a_{\mathrm{it}}, U D b_{\mathrm{it}}, U D c_{\mathrm{it}}, U D d_{\mathrm{it}}, U D e_{\mathrm{it}}\right)$ is measured as a per cent of the total unemployed for the following unemployment durations: 12 months or more $\left(U D a_{\mathrm{it}}\right)$, between 6 and 12 months $\left(U D b_{\mathrm{it}}\right)$, between 3 and 6 months $\left(U D c_{\mathrm{it}}\right)$, between 1 and 3 months $\left(U D d_{\text {it }}\right)$ and less than 1 month $\left(U D e_{\mathrm{it}}\right)$.

Unemployment benefits $\left(U B_{i t}\right)$ are measured in million euro, current prices and approximated as transfers to individuals out of work for maintenance and support, which mostly consist of unemployment benefits as part of labour market policy. Variable unemployment benefits were deflated by the harmonised index of consumer prices $\left(\mathrm{HICP}_{\mathrm{it}}\right)$. Data for the $\mathrm{HICP}_{\mathrm{it}}$ were obtained from Eurostat (prc_hicp_aind).

Job vacancy rates $\left(V R_{\mathrm{it}}\right)$ are defined as paid posts that are newly created, unoccupied or about to become vacant. Job vacancy rates measure the proportion of total posts that are vacant, according to the definition of job vacancy above, expressed as a percentage.

Gross domestic product $\left(G D P_{\text {it }}\right)$ is measured in million euro, current prices, and is the standard measure of value added created through the production of goods and services in a country during a certain period. As such, it also measures the income earned from that production, or total expenditures on final goods and services (less imports). Variable gross domestic product was deflated by the harmonised index of consumer prices $\left(\mathrm{HICP}_{\mathrm{it}}\right)$.

Active population by education attainment level - tertiary education $\left(A P E_{i t}\right)$ refers to individuals aged 15 to 64 with tertiary education (ISCED levels 5-8) measured in thousand persons.

Tax wedge $\left(T W_{\text {it }}\right)$ is defined as the ratio between the amount of taxes paid by an average single worker (a single person at $67 \%$ of average earnings) without children and the 
corresponding total labour cost for the employer. The average tax wedge measures the extent to which tax on labour income discourages employment. It is measured as a percentage of labour costs.

The time period of the data is between 2006 and 2018 for the EU-28 member states. Taking into account different approaches to social policy and to get more homogeneous groups of the EU-28 countries, we split the sample into sub-samples (South Europe, CEE region, Western Europe and North Europe). Our dataset thus contains both dimensions: cross-section dimension and time series/period dimension. Due to the availability of data our panel is unbalanced. In Tables 2-5 we present descriptive statistics for each sub-sample.

\subsection{Methods}

Panel regression models were used to gain insight into the relationship between unemployment benefits and duration of unemployment on the EU level, taking into account different approaches to social policy. Two-panel regression models were used, namely, the fixed effect model (FE) and random effect model (RE). The fixed effect estimator uses transformation to remove the unobserved effect prior to estimation. Any time-constant explanatory variables are removed along with the unobserved effects. The random effects estimator is appropriate when the unobserved effect does not correlate with all the explanatory variables and is, therefore, left in the error term. Alternatively, resulting serial correlations over time can be handled by generalized least squares estimations (see, for example Baltagi 2009; Kennedy 2011; Wooldridge 2013). The

Table 2. Descriptive statistics for the Southern Europe sub-sample

\begin{tabular}{|l|r|r|c|}
\hline Variable & Mean & Std. dev. & No. of obs. \\
\hline$U D a_{\text {it }}$ & 45.81 & 13.92 & 78 \\
\hline$U D b_{\text {it }}$ & 15.96 & 2.98 & 78 \\
\hline$U D c_{\text {it }}$ & 15.51 & 4.36 & 78 \\
\hline$U D d_{\text {it }}$ & 15.34 & 5.27 & 78 \\
\hline$U D e_{\text {it }}$ & 7.37 & 3.74 & 78 \\
\hline$U R_{\text {it }}$ & 12.17 & 6.46 & 78 \\
\hline$U R E 1_{\text {it }}$ & 14.98 & 8.08 & 78 \\
\hline$U R E 2_{\text {it }}$ & 12.28 & 7.28 & 78 \\
\hline$U R E 3_{\text {it }}$ & 8.23 & 4.85 & 78 \\
\hline$V R_{\text {it }}$ & 0.85 & 0.84 & 51 \\
\hline$G D P_{\text {it }}$ & $543,352.20$ & $653,348.80$ & 78 \\
\hline$A P E_{\text {it }}$ & $2,574.38$ & $2,956.47$ & 78 \\
\hline$T W_{\text {it }}$ & 37.42 & 3.58 & 52 \\
\hline$U B_{\text {it }}$ & $8,004.01$ & $10,917.58$ & 72 \\
\hline
\end{tabular}

Source: authors. 
Table 3. Descriptive statistics for the CEE sub-sample

\begin{tabular}{|l|c|c|c|}
\hline Variable & Mean & Std. dev. & No. of obs. \\
\hline$U D a_{\text {it }}$ & 48.64 & 10.57 & 104 \\
\hline$U D b_{\text {it }}$ & 17.53 & 2.90 & 104 \\
\hline$U D c_{\text {it }}$ & 14.13 & 3.60 & 104 \\
\hline$U D d_{\text {it }}$ & 12.18 & 4.10 & 104 \\
\hline$U D e_{\text {it }}$ & 7.52 & 3.60 & 104 \\
\hline$U R_{\text {it }}$ & 8.69 & 3.26 & 104 \\
\hline$U R E 1_{\text {it }}$ & 19.74 & 9.95 & 104 \\
\hline$U R E 2_{\text {it }}$ & 8.64 & 3.46 & 104 \\
\hline$U R E 3_{\text {it }}$ & 4.45 & 2.05 & 104 \\
\hline$V R_{\text {it }}$ & 1.17 & 0.83 & 88 \\
\hline$G D P_{\text {it }}$ & $5,083,200$ & $1,090,000$ & 104 \\
\hline$A P E_{\text {it }}$ & $1,332.47$ & $1,412.84$ & 104 \\
\hline$T W_{\text {it }}$ & 39.58 & 4.23 & 65 \\
\hline$U B_{\text {it }}$ & 328.37 & 222.66 & 90 \\
\hline
\end{tabular}

Source: authors.

duration of unemployment $\left(U D_{i t}\right)$ was treated as the dependent variable of the panel data regression models, whereas unemployment benefits $\left(U B_{i t}\right)$ were treated as the main explanatory variable of interest. Additionally, we included $U R_{i t} U R E_{i t} V R_{i t} G D P_{i b} A P E_{i t}, T W_{i t}$ as control variables. The basic specification of the two-way regression function can be demonstrated as follows:

$$
U D_{i t}=\alpha_{i}+\alpha_{i}+\beta_{1} U B_{i t}+e_{i t}
$$

\section{RESULTS}

In an attempt to gain insight into the relationship between unemployment benefits and duration of unemployment on the EU level, as well as different approaches to social policy, we split the whole sample into sub-samples. Our structure followed the principles of the geographical classification of sub-regions in Europe as defined by Eurovoc to get more homogeneous subsamples. We defined the following sub-samples for which we estimated the relationship between unemployment benefits and duration of unemployment: South Europe, ${ }^{1} \mathrm{CEE},{ }^{2}$ Western Europe ${ }^{3}$

${ }^{1}$ Spain, Portugal, Greece, Cyprus, Italy, Malta.

${ }^{2}$ Bulgaria, Czech Republic, Hungary, Poland, Romania, Slovakia, Slovenia, Croatia.

${ }^{3}$ Austria, Belgium, France, Germany, Ireland, Liechtenstein, Luxembourg, Netherlands, UK. 
Table 4. Descriptive statistics for Western Europe sub-sample

\begin{tabular}{|l|c|c|c|}
\hline Variable & Mean & Std. dev. & No. of obs. \\
\hline$U D a_{\text {it }}$ & 38.22 & 10.24 & 104 \\
\hline$U D b_{\text {it }}$ & 17.16 & 2.53 & 104 \\
\hline$U D c_{\text {it }}$ & 16.91 & 3.08 & 104 \\
\hline$U D d_{\text {it }}$ & 19.27 & 4.43 & 104 \\
\hline$U D e_{\text {it }}$ & 8.44 & 4.01 & 104 \\
\hline$U R_{\text {it }}$ & 6.93 & 2.55 & 104 \\
\hline$U R E 1_{\text {it }}$ & 12.39 & 4.23 & 104 \\
\hline$U R E 2_{\text {it }}$ & 7.05 & 3.25 & 104 \\
\hline$U R E 3_{\text {it }}$ & 3.94 & 1.39 & 104 \\
\hline$V R_{\text {it }}$ & 1.73 & 0.81 & 82 \\
\hline$G D P_{\text {it }}$ & $1,080,848$ & $1,014,305$ & 104 \\
\hline$A P E_{\text {it }}$ & $4,984.98$ & $4,833.07$ & 104 \\
\hline$T W_{\text {it }}$ & 37.31 & 9.32 & 104 \\
\hline$U B_{\text {it }}$ & $12,788.11$ & $14,385.84$ & 89 \\
\hline
\end{tabular}

Source: authors.

and North Europe. ${ }^{4}$ We performed modified a Wald test for group heteroscedasticity and a Wooldridge test for autocorrelation, which confirmed the presence of heteroscedasticity and autocorrelation respectively. To address the issue and obtain more reliable estimates we use robust standard errors. The choice between a fixed effects or random effects model was justified by performing a Hausman test. We present the estimation results for each sub-sample in Table 6.

Estimation results presented in Table 6 suggest similar results for South Europe and the CEE region, indicating that unemployment benefits are statistically significant and positively associated with unemployment durations up to twelve months or less. This may owe to the generosity of welfare systems, less incentives for finding a job, functioning of the employment services, non-motivational tax systems that decrease primary interest of people to work. After twelve months, the relationship is significantly negative. On the other hand, estimation results for Western Europe are comparably different from the results for Southern Europe and the CEE region, indicating more effective uses of public funds. This could be the result of different approaches towards social policy, highlighting that it is better to work rather than to be dependent on social benefits. The results for North Europe are statistically significant in case of short (less than one month) and long-term (more than twelve months) unemployment durations, whereas 
Table 5. Descriptive statistics for Northern Europe sub-sample

\begin{tabular}{|l|c|c|c|}
\hline Variable & Mean & Std. dev. & No. of obs. \\
\hline$U D a_{\text {it }}$ & 30.08 & 12.56 & 77 \\
\hline$U D b_{\text {it }}$ & 16.19 & 3.21 & 77 \\
\hline$U D c_{\text {it }}$ & 17.98 & 2.76 & 77 \\
\hline$U D d_{\text {it }}$ & 19.97 & 7.30 & 77 \\
\hline$U D e_{\text {it }}$ & 15.76 & 7.69 & 77 \\
\hline$U R_{\text {it }}$ & 8.67 & 3.46 & 78 \\
\hline$U R E 1_{\text {it }}$ & 18.33 & 8.2 & 78 \\
\hline$U R E 2_{\text {it }}$ & 9.15 & 4.42 & 78 \\
\hline$U R E 3_{\text {it }}$ & 4.64 & 1.56 & 78 \\
\hline$V R_{\text {it }}$ & 1.42 & 0.52 & 78 \\
\hline$G D P_{\text {it }}$ & $1,037,839$ & $1,493,737$ & 78 \\
\hline$A P E_{\text {it }}$ & 792.47 & 522.91 & 78 \\
\hline$T W_{\text {it }}$ & 38.63 & 2.93 & 78 \\
\hline$U B_{\text {it }}$ & $1,510.13$ & $1,480.36$ & 72 \\
\hline
\end{tabular}

Source: authors.

in other cases the results are not significant. It is interesting that greater vacancy rates are statistically significant and associated with greater unemployment durations in all examined approaches to social policy. This may be due to mismatches on the labour market and inflexible educational systems. Although not significant, the estimated results revealed that the greater the economic activity, the less pressure is put on unemployment benefits and the duration of unemployment. Moreover, in the case of Northern Europe, the higher tax wedge is significantly associated with longer periods of unemployment, whereas such results are also evident for other approaches to social policy but not statistically significant. Conclusively, estimation results revealed that the more generous the social policy, the more evident the negative relationship between unemployment durations and unemployment benefits.

\section{DISCUSSION AND IMPLICATIONS}

The system of social policy is essential since it replaces loss of income and provides basic income security to individuals. The biggest deficiency of such a system is that it does not stimulate active job searching.

Our results support findings presented in the literature review. Unemployment benefits are positively associated with unemployment durations up to twelve months or less. The results of several studies indicate that recipients tend to wait for benefits to expire before actively searching 
Table 6. Estimation results of panel regression for sub-samples

\begin{tabular}{|l|c|c|c|c|}
\hline Variable & $\begin{array}{c}\text { South EuropeRandom } \\
\text { effects GLS }\end{array}$ & $\begin{array}{c}\text { CEERandom } \\
\text { effects GLS }\end{array}$ & $\begin{array}{c}\text { EuropeRandom effects } \\
\text { GLS }\end{array}$ & $\begin{array}{c}\text { North EuropeFixed (within } \\
\text { group) effects }\end{array}$ \\
\hline Constant & 43.5304 & 8.2051 & 15.7265 & $-163.4922^{* *}$ \\
\hline UR & $-10.9749^{* * *}$ & $8.1750^{*}$ & -9.3261 & -8.1276 \\
\hline URE1 & $7.2928^{* * *}$ & 0.1292 & 1.2049 & $1.8405^{* *}$ \\
\hline URE2 & $1.4069^{* *}$ & $-6.8665^{*}$ & $7.2988^{* *}$ & 3.5784 \\
\hline URE3 & $3.3017^{*}$ & 2.0154 & 1.7656 & 4.2747 \\
\hline VR & $3.6069^{* *}$ & $2.2752^{*}$ & $4.0598^{* *}$ & $9.7486^{* *}$ \\
\hline GDP & -0.0001 & -0.0001 & -0.0001 & -0.0001 \\
\hline APE & -0.0038 & 0.0009 & -0.0011 & -0.0055 \\
\hline TW & 0.0988 & 0.5203 & 0.1321 & $4.5909^{* *}$ \\
\hline UBa & $-0.0007^{* *}$ & $-0.0225^{* * *}$ & $0.0008^{*}$ & -0.0012 \\
\hline UBb & $0.0004^{* *}$ & $0.0124^{* * *}$ & -0.0001 & 0.0044 \\
\hline UBc & $0.0003^{* *}$ & $0.0080^{* * *}$ & -0.0002 & 0.0014 \\
\hline UBd & 0.0000 & $0.0073^{* * *}$ & -0.0002 & $-0.0009^{*}$ \\
\hline UBe & -0.0001 & $-0.0053^{*}$ & $-0.0004^{* *}$ & 0.0004 \\
\hline $\mathrm{R}^{2}$ & 0.9333 & 0.8875 & 0.7677 & 0.6190 \\
\hline Hausman & 8.42 & 4.51 & 11.52 & $19.98^{* *}$ \\
\hline test & & 53 & 68 & 56 \\
\hline No. of & 33 & & & \\
\hline obs. & & & & \\
\hline
\end{tabular}

Notes. UBa - estimation of the coefficient when dependent variable is UDa; UBb - estimation of the coefficient when dependent variable is UDb; UBc - estimation of the coefficient when dependent variable is UDc; UBd estimation of the coefficient when dependent variable is $U D d ; U B e$ - estimation of the coefficient when dependent variable is UDe. ${ }^{* * *}$ Significance level at $1 \%,{ }^{* *}$ Significance level at $5 \%,{ }^{*}$ Significance level at $10 \%$ Source: authors.

for employment. In the majority of countries, unemployment benefits are most generous at the beginning of a claim and unemployed persons tend to prolong this benefit as long as they can. The generosity of a welfare system causes a moral hazard effect, consequentially lowering motivation to find new employment. Ideally, this should result in stricter monitoring of claimants' behaviour and whether or not they are actively searching for a job. Unemployment benefits, in combination with high taxation of income, can also deter an individual from employment. Moreover, the functioning of the employment services also matters. It is important to increase response times of the employment service because this has great importance for the success of an individual in the reintegration into the labour market. Therefore, consultants 
should strive for effective training, education and communication that could stimulate the person to actively search for jobs.

The effects of unemployment benefits on the labour market depend particularly on the characteristics of the social policy system, including the conditions for acquiring and maintaining benefits, as well as implementing them in practice, labour market conditions and characteristics of labour supply and demand. Results indicate that a major part of Northern and Western European countries use public funds more effectively than CEE and Southern European countries. This could be due to different approaches to social policy. Citizens of Nordic and Western European regions exhibit higher levels of confidence in public systems. Funds are mostly used on preventative measures, meaning that unemployment is relatively low. Their social policy highlights that it is better to work than to be dependent on social benefits. However, their social model is difficult to apply in large heterogeneous countries with high unemployment. Training and support for specific groups of the population i.e. low-skilled, long-term unemployed, mature workers, young and single mothers is relatively difficult to implement in a context where labour demand is too low.

Designing a social policy system and choosing the various parameters, such as benefit levels and durations involve finding a balance between providing insurance to unemployed individuals, whilst simultaneously not being detrimental to their incentive for finding work (Schmieder - Wachter 2016). They should be organized in a way to enable faster reintegration in the labour market. This means an additional reinforcement of measures to prevent transition to long-term unemployment, which mostly leads to inactivity and consequently slower development of the economy since the country does not take advantage of its full potential.

All measures should be supported with effective active labour market policy, as financial compensation alone cannot motivate individuals to seek employment. Passive labour market policies for a longer period of time with little to no active strategies lead to a larger number of long-term unemployment (O'Higgins 2010). In the future, measures should show results in measurable indicators. Measurement of the results and evaluation of programs are important because we cannot know otherwise which programs are effective and which only hide social problems. Moreover, the ones which do not have positive effects on the development of individuals represent a high cost to the public funds.

\section{CONCLUSIONS}

Social transfers have many different effects on the labour market and on the behaviour of unemployed people. First of all, by increasing the value of unemployment, they increase the reservation wage. This means that the unemployed become more selective in choosing and waiting for a better offer. Second, they can lead to lowering the motivation for job search, especially if the duration of the entitlement to benefits is longer. It can also come to the situation where people bend the rules and become unemployed only to receive the benefits and not due to an active job search. The effect of cash transfers is most visible on exit points when the rate of outflow increases significantly along with the right to entitlement to unemployment benefits. This means that recipients wait for the right to expire before they start to search for a new job intensively or, in another case, simply withdraw from the unemployment records. 
In this paper we analysed the relationship between unemployment benefits and duration of unemployment with respect to different approaches to social policies among EU countries, using panel data regression approach. According to the results, we can conclude that unemployment benefits that represent a majority of funds within a passive labour market policy produce counter-effects and increase the duration of unemployment, confirming our paper's hypothesis. It is difficult to reduce unemployment, in particular when effective measures are not taken. It is important to consider the role of social security and ensuring an appropriate amount of unemployment benefits. Regardless, it would be necessary to reduce a population's dependence on social benefits and ensure welfare in a larger extent through employment. We stipulate that social security systems should be reorganized, especially in a way that optimizes a faster reintegration into the labour market. It is especially important to strengthen the collaboration between employment services and the unemployed persons to provide suitable motivation for the unemployed, and to promote the culture of evaluation of labour market policies. The availability of data on the individual level represented the major limitation to our research, disabling us to use different microeconometric techniques to evaluate the effectiveness of different employment programmes. The latter is seen as a possible orientation for future research.

The findings of our research can be of help to labour market decision-makers and in the development of new innovative suggestions for employment measures for different groups of unemployed people (e.g. youth, older, other disadvantaged groups on the labour market), tailored to the needs and specifics on the labour market. New innovative suggestions are to address entrepreneurial awareness, the development of entrepreneurial training courses to promote entrepreneurship, self-employment or social entrepreneurship which increase the employability of the unemployed people, the creation of new employment options, and improve skills and competencies for future jobs.

\section{REFERENCES}

Aaronson, D. - Mazumder, B. - Schechter, S. (2010): What is Behind the Rise in Long Term Unemployment? Economic Perspectives 34(3/4): 28-51.

Baltagi, B. H. (2009): Econometric Analysis of Panel Data. Hoboken: Wiley.

Barbanchon, T. - Rathelot, R. - Roulet, A. (2017): Unemployment Insurance and Reservation Wages: Evidence from Administrative Data. Journal of Public Economics 171: 1-17.

Beblavý, M. - Lenaerts, K. (2017): Feasibility and Added Value of a European Unemployment Benefits

Scheme. Brussels: The Centre for European Policy Studies.

Bohle, D. - Greskovits, B. (2007): Neoliberalism, Embedded Neoliberalism and Neocorporatism: Towards

Transnational Capitalism in Central-Eastern Europe. West European Politics 30(3): 443-466.

Card, D. - Johnston, A. - Leung, P. - Mas, A. - Pei, Z. (2015): The Effect of Unemployment Benefits on the Duration of Unemployment Insurance Receipt: New Evidence from a Regression Kink Design in Missouri. American Economic Review 105(5): 126-130.

Delgado, M. A. - García-Suaza, A. - Sant'Anna, P. H. C. (2019): Distribution Regression in Duration Analysis: An Application to Unemployment Spells. https://arxiv.org/abs/1904.06185, Accessed 26 February 2020. 
Dolenc, P. - Laporšek, S. (2013): Flexicurity Policies and their Association with Productivity in the European Union. Prague Economic Papers 22(2): 224-239.

Dolenc, P. - Laporšek, S. - Spruk, V. - Vodopivec, M. - Vodopivec, M. - Zupančič, B. (2012): Empirična analiza učinkov uvedbe zakona o urejanju trga dela. https://www.stat.si/StatisticniDnevi/Docs/Radenci \%202012/prispevki/Dolenc\%20-\%20ZUTD.pdf, Accessed 11 January 2019.

Dospial-Borysiak, K. (2017): Northern Europe. New Political, Economic and Social Trends. Interdisciplinary Political and Cultural Journal 20(1): 7-11.

EASPD (2014): Social welfare systems across Europe. https://www.easpd.eu/en/content/sensage, Accessed 2 March 2020.

Eurostat (2019): Eurostat database. Available at: https://ec.europa.eu/eurostat/data/database, Accessed 15 January 2019.

Farber-Valletta, S. G. R. (2015): Do Extend Unemployment Benefits Lengthen Unemployment Spells? Evidence from Recent Cycles in the US Labour Market. Journal of Human Resources 50(4): 879-909.

Ferrera, M. (2013): 6th EU-India Joint Seminar on Employment and Social Policy. https://ec.europa.eu/ social $/$ main.jsp?catId $=88 \&$ langId $=$ en\&eventsId $=853 \&$ moreDocuments $=$ yes\&tableName $=$ events\&typeId $=92$, Accessed 2 March 2020.

Fialová, K. - Schneider, O. (2009): Labor Market Institutions and their Effect on Labor Market Performance in the New EU Member Countries. Eastern European Economics 47(3): 57-83.

Fujita, S. (2010): Economic Effects of the Unemployment Insurance Benefits. Business Review Issue Q4: 2027.

Fradkin, A. - Scott, B. (2017): The Impact of Unemployment Insurance on Job Search: Evidence from Google Search Data. Review of Economics and Statistics 99(5): 756-768.

Groot, N. - Klaauw, B. (2014): The Effects of Reducing the Entitlement Period to Unemployment Insurance Benefits. IZA Discussion paper 8336.

Halaskova, R. (2018): Structure of General Government Expenditure on Social Protection in the EU Member States. Montenegrin Journal of Economics 14(4): 7-21.

Hassett, K. A. (2014): The Unemployment Trap. National Review 66(3): 8.

Hijzen, A. - Salvatori, A. (2020): Designing Fair and Work-Oriented Unemployment Benefits: The Case of Belgium. OECD Employment and Migration Working Papers 237.

Hornstein, A. - Lubik, T. A. (2015): The Rise in Long Term Unemployment: Potential Causes and Implications. Economic Quarterly 101(2): 125-149.

Italo, A. G. (2019): Do Unemployment Benefits Affect on the Job Search? Evidence from Labor Turnover before Establishment Closures. Economic Inquiry 57(3): 1421-1440.

Južnik Rotar, L. (2013): Analysing the Effects of Unemployment Benefits and Active Labour Market Policies on the Labour Market Outcomes. In: Umihanić, B. - Rebernik, M. (eds): ICEI 2013: Z znanjem od recesije ka prosperitetu: zbornik radova. Tuzla: Univerzitet u Tuzli, Ekonomski fakultet.

Kennedy, P. (2011): A Guide to Econometrics. Malden: Blackwell.

Kluzen, S. - Redecker, C. - Centeno, C. (2010): In: Long-term Care Challenges in an Ageing Society: The Role of ICT and Migrants: Result from a study in England. Germany, Italy and Spain: European Commision, Brussels.

Kroft, K. - Notowidigdo, M. J. (2016): Should Unemployment Insurance Vary with the Unemployment Rate? Theory and Evidence. The Review of Economic Studies 83(3): 1092-1124.

Kyyrä, T. - Pesola, H. (2017a): Estimating the Effects of Potential Benefit Duration without Variation in the Maximum Duration of Unemployment Benefits. VATT Institute for Economic Research Working Paper 87. 
Kyyrä, T. - Pesola, H. (2017b): The Effects of UI Benefits on Unemployment and Subsequent Outcomes: Evidence from Kinked Benefit Rule. IZA Discussion paper 10484].

Laporšek, S. - Dolenc, P. (2012): Do Flexicurity Policies Affect Labour Market Outcomes? An Analysis of EU Countries. Revija za socialnu politiku 19(2): 107-129.

Lauzadyte-Tutliene, A. - Balezentis, T. - Goculenko, E. (2018): Welfare State in Central and Eastern Europe. Economics \& Sociology 11(1): 100-123.

Lengyel, G. - Göncz, B. - Tóth, L. (2017): Expected Long-term Labour Market Resilience and the European Union's Perceived Role - Results of an Online Policy Delphi. Society and Economy 39(2): 165-182.

Lichter, A. (2017): Benefit Duration and Job Search Effort: Evidence from a Natural Experiment. IZA Discussion paper 10264.

Marinescu, I. (2017): The General Equilibrium Impacts of Unemployment Insurance: Evidence from a Large Online Job Board. Journal of Public Economics 150: 14-29.

Marinescu, I. - Skandalis, D. (2018): Unemployment Insurance and Job Search Behaviour. Available at: https://ssrn.com/abstract=3303367, Accessed 21 January 2019.

Mathieu, C. - Sterdyniak, H. (2008): European Social Models(s) and Social Europe. Working Paper 2008-10 Paris: OFCE.

Nekoei, A. - Weber, A. (2015): Does Extending Unemployment Benefits Improve Job Quality? Discussion paper 9034. Bonn: IZA Institute of Labour Economics.

Nordic Welfare Centre. (2020): Welfare policy. https://nordicwelfare.org/en/welfare-policy, accessed 2 March 2020.

OECD. (2019): OECD Database. https://stats.oecd.org/, Accessed 6 January 2019.

O'Higgins, N. (2010): The Impact of the Economic and Financial Crisis on Youth Employment: Measures for Labour Market Recovery in the European Union, Canada and the United States. Geneva: ILO.

Popova, Y. - Kozhevnikova, M. (2013). Interdependence of HDI and Budget Redistribution within the Scandinavian and Continental Social Models. Economics and Management 18(3): 562-575.

Rebollo-Sanz J. F. - Rodríguez-Planas N. (2018): When the Going Gets Tough...: Financial Incentives, Duration of Unemployment, and Job-Match Quality. Human Resources 55: 119-163.

Rothstein, J. (2011): Unemployment Insurance and Job Search in the Great Recession. Brookings Papers on Economic Activity 42(2): 143-213.

Rothstein, J. - Valletta, R. G. (2017): Income and Program Participation After the Loss of Extended Unemployment Benefits. Journal of Policy Analysis and Management 36(4): 880-908.

Schmeider, J. F. - Wachter, T. - Bender, S. (2015): The Effect of Unemployment Benefits and Nonemployment Durations on Wages. American Economic Review 106(3): 739-777.

Schmieder, J. F. -Wachter, T. (2016): The Effects of Unemployment Insurance Benefits: New Evidence and Interpretation. Annual Review of Economics 8(1): 547-581.

Scrutinio, V. (2019): The Medium-Term Effects of Unemployment Benefits. London School of Economics Working Paper 18.

Stefanovska-Petrovska, M. - Bojadziev, M. (2017): Cash or Compliment? Older employees preference of financial versus non-financial incentives. Montenegrin Journal of Economics 13(1): 63-71.

Tatsiramos, K. (2006): Unemployment Insurance in Europe: Unemployment Duration and Subsequent Employment Stability. IZA Discussion Paper 2280.

Tatsiramos, K. - Ours, J. C. (2012): Labour Market Effect of Unemployment Insurance Design. Journal of Economic Surveys 28(2): 284-311. 
Trasca, L. D. - Stefan, M. G. - Aceleanu, M. I. - Sahlian, D. N. - Stanila, G. O. - Hoinaru, R. (2019): Unique Unemployment Insurance Scheme in Euro Zone. Terms and Conditions. Impact. Economic Computation and Economic Cybernetics Studies and Research 53(2): 241-256.

Tvrdon, M. (2015): Labour Market Performance in EU Member States: A Panel Regression Approach. Journal of Economics, Business and Management 3(1): 34-37.

Valletta, R. (2014): Recent Extensions of U.S. Unemployment Benefits: Search Responses in Alternative Labour Market States. IZA Discussion paper 8247.

Van Beek, L. (2011): The Effect of the Unemployment Benefit System on the Motivation to Re-enter the Labour Market. https://www.netspar.nl/assets/uploads/031_BSc_Lisanne_van_Beek.pdf, accessed 22 December 2018.

Williamson, S. D. (2006): Macroeconomics: International Edition. Harlow: Pearson Education.

Wooldridge, J. M. (2013): Introductory Econometrics: A Modern Approach. Sydney: South Western.

Open Access. This is an open-access article distributed under the terms of the Creative Commons Attribution-NonCommercial 4.0 International License (https://creativecommons.org/licenses/by-nc/4.0/), which permits unrestricted use, distribution, and reproduction in any medium for non-commercial purposes, provided the original author and source are credited, a link to the CC License is provided, and changes - if any - are indicated. 